\title{
SPOREFORMING BACILLUS BIOEFFECTORS FOR HEALTHIER FRUIT QUALITY OF TOMATO IN POTS AND FIELD
}

\author{
DUdÁs, A. ${ }^{1}$-SZALAI, Z. M. ${ }^{2}$ - VIDÉKI, E. ${ }^{1}$ - WASS-MATICS, H. ${ }^{1}$ - KOCSIS, T. ${ }^{1}$ - VÉGVÁRI, GY. ${ }^{1}$ - \\ KOTROCZÓ, ZS. ${ }^{1 *}-$ BIRÓ, B. ${ }^{1 *}$ \\ ${ }^{I}$ Department of Soil Science and Water Management, Szent Istvan University \\ H-1118 Budapest, Villanyi ut 29-43, Hungary \\ ${ }^{2}$ Department of Ecological and Sustainable Production Systems, Szent Istvan University \\ H-1118 Budapest, Villanyi ut 29-43, Hungary \\ *Corresponding authors \\ e-mail:biro.borbala@kertk.szie.hu
}

Zsolt Kotroczó and Borbála Biró contributed equally.

(Received 26 $6^{\text {th }}$ Mar 2017; accepted 20 Jul 2017)

\begin{abstract}
Biologically active compounds, sugars, acids and antioxidants are key-important ingredients of healthy tomato food. Objective of the study is to investigate if specific industrial bioeffector products are improving the taste and some quality parameters of tomato fruits and how those results are appearing in pots and among organic field conditions? Spore-forming industrial Bacillus amyloliquefaciens FZB42 (RhizoVital) as single inoculums and combinations either with other Bacillus strains (Biorex-1), or with $\mathrm{N}_{2}$-fixing-siderophore-producing strains (Biorex-2) were applied on Solanum lycopersicon Mill. var. Mobil test plant. Soil microbial counts, phosphorus availability and fruit quality, such as total soluble solids (TSS), content of some essential organic acids (citric-, maleic) and sugars (glucose, fructose) were assessed. The results found, that single industrial inoculums of FZB42 product had positive effect on Pavailability and fruit quality in the pots, combinations of other biofertilizers, however, did not give additional results. Fruit quality parameters, TSS content, soluble sugars and organic acids were significantly improved $(\mathrm{p}<0.05)$ at both experimental conditions. Such better fruit taste was correlated significantly by the most probable number (MPN) total microbial counts with greater positive values in pot experiment, compared with more variable environmental field condition. The recommendation of using such bioeffector products is supported by the positive interrelation among measured soil characteristics and inside healthy quality parameters of organically grown tomato fruits.
\end{abstract}

Keywords: bioeffectors, biofertilizers, phosphate solubilization, tomato quality, organic agriculture, MPN counts, correlation

\section{Introduction}

Sustainable agriculture and healthy food become one of the most important aspects of any food-production systems. An increasing demand exists for fruits and vegetables of originating from ecological farming systems, avoiding the use of chemical fertilizers and pesticides (FIBL 2001; Hesammi et al., 2014; Kocsis et al., 2017). As a direct consequence of intensive agricultural production, deleterious environmental effects on soil-quality and fertility are increasing in parallel loss of the abundance and diversity of living organisms in soil-food-web (Johnston, 1986; Varga et al., 2007). Key important requirements therefore is the needs of reducing the artificial deleterious chemicals and xenobiotic inputs, more particularly among the agri- and horticultural practices (Juhos et al., 2015, 2016). Altogether with those conditions consumers' highlighted expectation for healthy and chemical-free foods are simultaneously required. 
Depending on the variability of environmental conditions 3-15 t microorganisms can be found in each hectare of the soils, not considering other soil-fauna elements of soilfood-web (Fekete et al., 2008; Kotroczó et al., 2008; Veres et al., 2013). For a correct assessment of soil edaphon, several parameters are investigated and variability of methods used, as a function of the aim and applicability of investigations. It is generally accepted, however that biological activity of soil organisms might play a crucial role in mobilization of soil nutrients and make them available and usable for higher plants, crops (Juhos, 2014). Several organisms are known to be involved in soil organic matter degradation and decomposition (Kotroczó et al., 2014a, b; Fekete et al., 2014, 2017; Veres et al., 2015) and giving with this process continuously the available nutrients for higher plants (Tóth et al., 2013). Various microbial diversity and types of microorganisms are living in the soils, including both of bacteria and fungi with known general and/or highly specific nutrient mobilization ability (Schweitzer et al., 2008). In recent decades' chemical fertilization was the most dominant in intensive agricultural production. By contrast active microbial soil characteristics were largely ignored, due to the mainly artificial plant nutrient fertilizing practices among the intensive agriculture production.

Concern for the above mentioned reasons for healthy environment, eco-friendly production methods and chemical-free farming systems are increasing (den Hollander et al., 2007). One of the most accepted and followed alternatives of intensive agricultural practices are the application of living bioeffectors (BE), which might include one or more types and strains of so called "beneficial microorganisms" in many soil-plant systems. Other, so-called non-living bioeffector materials (carriers, soil-ameliorative compounds, natural minerals) can be used in parallel with the generally accepted biofertilizer, bioeffector treatments. Such combined application is providing both living organisms and also soil-improving materials; finally, the survival of microbes and soil functions might be enhanced in one step. The selected beneficial microbes are known to support plant-growth and development, nutrient and water uptake of plants and might suppress damage of harmful soil-borne plant pathogen microorganisms in soil-plant systems. Bioeffectors can successfully integrate into any environmental-friendly agrihorti-, silvi- and viti-cultural practices. Main accepted application of bioeffectors is reducing or diminish fertilizer and high levels of pesticide inputs. Among beneficial microorganisms, the symbiotic connection between plant growth promoting bacteria (PGPB) or -rhizobacteria (PGPR) and their host plants was first described and demonstrated by Kloepper and Schroth (1978). PGPB or PGPR microorganisms have a potentially great impact on plant growth, yield and health with several known mechanisms in soil-plant systems. Those organisms might protect cultivated plants from soil-borne plant pathogens in addition they can improve soil chemical and physical characteristics (Glick et al., 2007). By using PGPB microorganisms as introduced inoculums of soils, nitrogen and phosphorus content, other mezo-micro-elements become available by plants. This mechanism can result harmonized nutrient balance in soils and might heal nutrient disorders in soils. As a direct consequence of inoculation, amount of synthetic fertilizers, furthermore other xenobiotics, toxic agrochemicals will be reduced (Hay et al., 2010).

Direct and indirect beneficial effects and mechanisms of bioeffectors are reported from any soil-plant-microbe systems, with known distinct and well-characterized effects. The combination of those described mechanisms are also possible, and different bacteria or fungal species might have more than one of these functional traits. Schippers 
et al. (1985) described three different affecting mechanisms in plant-soil-microbe systems:

- increased nutrient supply, nitrogen fixation, nutrient exploration or nutrient transport,

- increased defence mechanisms against some soil-borne plant pathogen fungi and bacteria by inhibiting of their growth; competition for space and for nutrients, antibiosis, parasitism, induced systemic resistance;

- direct enhancement of plant growth, production of several hormone-like, plant growth regulating (PGR) substances.

These protected effects can overlap in many cases and different microorganisms can also have more than one efficient PGPR or plant growth regulating (PGR), hormonelike mechanisms. In several occasions not all of these effects might be developed, due to the fact, that they might be modified during the vegetation periods through the various biotic and abiotic environmental (stress) factors (Biró et al., 2000; Carvalhais et al., 2013). Those particular effects are especially specific for combined "second-generation" of microbial inoculums, where microorganisms as specifically adapted ones were used to certain environment and for certain host plants. Specific bioeffective and stresstolerant microbes therefore are used efficiently at the practice of amelioration, recultivation and/or at remediation practices (Biró et al., 2000; 2012).

Phosphorus supply is key issue for optimal tomato production. Necessity of Pelements are especially crucial at early stage of plant growth. Presence of phosphorusmobilizing microorganisms as Bacillus spp. bacteria, furthermore the fluorescens and putida types of Pseudomonas spp., which can influence indirectly the uptake of this element is also essential (Khan et al., 2009). Those microorganisms are able to mobilize hardly available phosphorus forms (Bashan et al., 2013) e.g. they can solubilize natural rock phosphates to be available for plants, improving the growth of roots, shoots and plant biomass or fruits. Due to those beneficial properties, bioeffector organisms are successfully involved in ecological farming practices (Hariprasad and Niranjana, 2009; Biró et al., 2012). Among bioeffector (BE) strains, those with spore-forming abilities are more tolerant and survivor at serious environmental stress conditions, therefore their application is highly expanded in industrial microbial inoculum productions (Hartmann et al., 2009).

The Bacillus amyloliquefaciens is a non-pathogenic soil bacterium. Similar to other Bacillus species it is capable of producing endospores allowing it to survive for extended periods of time. The species also shows some antifungal properties which are influenced by several environmental factors, including nitrogen availability (Caldeira et al., 2008; Choudry et al., 2015). Bacillus spp., i.e. B. subtilis is known as efficient in cellulose degradation, amylase production and can block phytopathogenic microorganisms (Yang et al., 2009). B. thüringiensis is generally used against soil pests, by creating an alkaline reaction and leading to the serious pest destruction. B. megaterium is efficient in phosphate mobilization, the production in growth substances and vitamin B12 and it is also possible to modify the plant residues into humus.

Among beneficial microorganisms the nitrogen $\left(\mathrm{N}_{2}\right)$-fixing bacteria are having the uppermost importance, including as free-living, associative and obligate symbiont forms in soil-plant systems. Azotobacter chroococcum bacteria are free-living nitrogen fixing microbes, generally with drought and cold tolerance (about $3-4{ }^{\circ} \mathrm{C}$ of soil temperature) ability Azospirillum lipoferum is an associative nitrogen fixing bacteria, which secondary interact with the roots of monocots and also known as auxins, gibberellins, cytokinin plant 
hormone producer (Biró et al., 2000; Diamantidis et al., 2000). Pseudomonas putida as other frequently used biofertilizer species, might produce siderophore-like compounds, efficiently using of iron ions from soil and it creates also some competitive inhibition towards soil-borne plant-pathogen organisms and in addition enhance plant-uptake of macro-, mezo-and micro-nutrients (Timmis, 2002). Among ecological farming production systems, the use of bioeffector treatments, including the biofertilizer and/or the biopesticide effect of microorganisms seems to be the only and highly feasible way of thinking (Rodriguez and Fraga, 1999; Biró et al., 2000).

Tomato is one of the most frequent vegetable grown worldwide and consumed both in freshed and in processed forms (Helyes et al., 2014). This tasty vegetable has important role in healthy lifestyle, sustainable tomato production has therefore an increasing demand nowadays. In order to achieve the highest possible yield, unreasonable tillage and overuse of agrochemicals (pesticides, chemical fertilizers) are applied at intensive growing systems (Glendining et al., 2009). Such breeding practices on the other hand generally reduce the nutritional value of crops, vegetables and also of the fruits. Tomato on the other hand might contain significant amounts of natural health-protecting compounds, such as the organic acids, sugars and antioxidant materials, such as the lycopene, C-vitamins and others (Devi et al., 2008; Helyes et al., 2014).

Soluble sugars and organic acids play crucial role in tomato quality and food taste values. Tomato contains 5.0-7.5 \% of dry matter that is mainly constituted of fructose, glucose, citric acid, malic acid, and other organic compounds (Sariyer and Oztokat, 2015; Salles et al., 2003). Major organic acids in tomatoes are citric- and malic acids, with higher dominance of citric-acids (Davies and Hobson, 1981). Levels of organic acids are highly depending on the ripeness and also on the certain cultivars, beside the crucial soil-environmental affecting factors (Baldwin et al., 1991; Béni et al., 2014, 2017). Phosphorus supply of tomato plants influences highly the quantity and quality of biologically active compounds in the fruits (Di Cesare et al., 2010). Several keyimportant compounds of organic acids and sugars were examined therefore by high performance liquid chromatography (HPLC) beside the total soluble solid (TSS) content from ripe fruits.

Effect of some commercially available microbial fertilizer (bioeffector) inoculations, including spore-forming bacteria was studied on the fruit quality parameters of tomato among controlled light-chamber and at field-conditions. Main focus was given for answering of the following questions: Is Bacillus spp. biofertilizer inoculation increasing the soil microbial counts and available P for plants? Is some of inside tomato fruit quality parameters improved by the bioeffector inoculations? Is there any positive correlation between the bioeffector treatments and fruit quality? Is results from pots can be predictable to up-scaled natural field condition?

\section{Materials and methods}

\section{Experimental background}

Experiments were carried out in pots and also among organic field conditions in 2014. There were 4 different treatments used in the pot experiment of applying $3 \mathrm{dm}^{3}$ of pots in 4 replicates (Table 1). Among field conditions there were 12 of $4 \times 5 \mathrm{~m}$ plots used at the Research and Experimental Farm of the Szent István University of Budapest, Horticultural Faculty, Ecological Farming Division in Soroksár, Hungary (N 4740’; E 
$19^{\circ} 15^{\prime}$ at $111 \mathrm{~m}$ altitude). Ecological farming practices are carried out since more than ten years on the experimental field site. For nutrient supplementation we applied authorized substances used in organic farming: Viano $\left(13 \% \mathrm{~N} ; 660 \mathrm{~kg} \mathrm{ha}^{-1}\right)$, Patentkali $\left(30 \% \mathrm{~K}_{2} \mathrm{O} ; 10 \% \mathrm{MgO} ; 17 \% \mathrm{~S} ; 1200 \mathrm{~kg} \mathrm{ha}^{-1}\right)$. Regarding plant protection against soil borne plant pathogens during the vegetation periods, we used copper-sulphatecontaining fungicide (Cuproxat FW-1) treatment according to the suggestion of suppliers. Experimental area was regularly watered of using drip irrigation system. Some of the soil characteristics and also some data about environmental climatic conditions of the area are shown in Table 1. In 2014 it was an excessively rainy growing season with almost 1.5-times higher precipitation than the usual average annual value.

Table 1. Main characteristics of soil at Soroksár site, Hungary

\begin{tabular}{|c|c|}
\hline Soil parameters & Measured values \\
\hline $\mathrm{pH}_{\mathrm{H} 2 \mathrm{O}}$ & 7.9 \\
\hline $\mathrm{C}: \mathrm{N}$ (A horizon) & 9.92 \\
\hline $\mathrm{NO}_{2}+\mathrm{NO}_{3}-\mathrm{N}$ & $8.5 \mathrm{mg} \mathrm{kg}^{-1}$ soil \\
\hline $\mathrm{P}(\mathrm{CAL})$ & $43 \mathrm{mg}$ (100 g $\mathrm{g}^{-1}$ soil $)$ \\
\hline $\mathrm{K}(\mathrm{CAL})$ & $17\left(100 \mathrm{~g}^{-1}\right.$ soil $)$ \\
\hline $\operatorname{Mg}\left(\mathrm{CaCl}_{2}\right)$ & $10\left(100 \mathrm{~g}^{-1}\right.$ soil $)$ \\
\hline Soil type & slightly hummus sandy soil \\
\hline Mean annual temperature & $11^{\circ} \mathrm{C}$ \\
\hline Mean annual precipitation & $500 \mathrm{~mm}$ \\
\hline
\end{tabular}

Pot experiment was performed in the light-chamber of Department of Soil Science and Water Management of Corvinus University (now it belongs to Szent István University), Budapest, Hungary. Soil used in the pots, was originated from the field experimental station of Soroksár, Hungary. Light-period of pot experiment was 14 hours in a daily basis in accordance with the requirements of the tomato plants. Pots were placed in a controlled-temperature light room, programmed at a temperature ranging from $17^{\circ} \mathrm{C}$ to $28^{\circ} \mathrm{C}$, while the light intensity (Lux) had been $25000 \mathrm{~lx}$ (Herrera et al., 2008). Characteristics of applied soil are shown in Table 2. Both in pots and in field experiments the tomato (Solanum lycopersicon Mill.) Hungarian cultivar of 'Mobil' were used. Seedlings were grown under controlled conditions and planted into their final place after the $14^{\text {th }}$ days, preferably at the same stage of maturity of each. The pot experiment was carried out between $31^{\text {st }}$ of March 2015 and $16^{\text {th }}$ of June 2015. In case of field trials, the seedling was grown up till the $25^{\text {th }}$ of March 2015 in cold plastic house, transplanting of small 2-leaves of seedlings was done to bigger pots at $9^{\text {th }}$ of May 2015. Final seedlings-transplantation to the field condition was performed between 2026 of May 2015.

Regarding the plant parameters, a biweekly visual inspection of plant-parameters was done during the vegetation periods (data not shown), and a final biomass-production of fresh and dry weight of shoot was estimated. Fruits of tomato was regularly measured from each of the tomato plants, and a summary of the yield was calculated in each plots and in each treatment. In this study we are focusing on the soil- and fruit- quality parameters. 


\section{Biofertilizer treatments and estimation of soil-characteristics}

Commercially available bioeffectors (BE products), i. e. biofertilizers, were used for both at the pots and the field experiment. On the basis of the results achieved in pot experiment, combinations of $\mathrm{BE}$ with other product of biofertilizers were also tested among field conditions according to Table 2 .

During general set-up of pot experiment, there were $2500 \mathrm{~g}$ air-dried soil put in each of the pots and one tomato seedling/pot was planted. Biofertilizers were applied on the basis of supplier suggestions. Bioeffector (BE) strains were used in the rates of $1.33 \%$ (v/v), i.e. $0.2 \mathrm{ml}$ for each plants Hungarian BR1 and BR2 products, as a 2-componentbiological fertilizer was also applied according to the supplier's protocol, BR1: 0.1875 ml.plant ${ }^{-1}$; BR2: 0.375 ml.plant $^{-1}$, shown in Table 2.

Ammonium lactate method (P-AL) was used to estimate available phosphorus content: $5 \mathrm{~g}$ of soils were shaken in $100 \mathrm{ml}$ of $0.1 \mathrm{M}$ ammonium lactate and $0.4 \mathrm{M}$ acetic acid ( $\mathrm{pH}$ 3.75) for 1 hours and phosphorus content was estimated from the filtrate colorimetrically (Egner et al., 1960).

Table 2. Treatments and density of bioeffector inoculums at the pot and field experiment

\begin{tabular}{|c|c|c|c|}
\hline Treatments & Bioeffector strains & 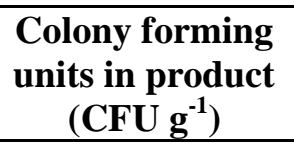 & Inoculation rates \\
\hline $\mathrm{C}$ (Control) & No inoculums, only water & - & - \\
\hline $\begin{array}{c}\text { BE } \\
\text { (Bioeffector) }\end{array}$ & $\begin{array}{c}\text { Bacillus amyloliquefaciens } \\
\text { FZB42 }\end{array}$ & $2.5 \times 10^{10}$ & $\begin{array}{c}1.33 \%(\mathrm{v} / \mathrm{v}) \text {, i.e. } 0.2 \\
\mathrm{ml} / \mathrm{plant}\end{array}$ \\
\hline $\begin{array}{c}\text { BR1 } \\
(\text { Biorex-1) }\end{array}$ & $\begin{array}{l}\text { Bacillus subtilis; } B . \\
\text { thüringiensis; } B . \text { megaterium }\end{array}$ & $2 \times 10^{10}$ & $\begin{array}{c}5 \mathrm{~L} / \mathrm{ha}, \\
0.1875 \mathrm{ml} / \mathrm{plant}\end{array}$ \\
\hline $\begin{array}{c}\text { BR2 } \\
\text { (Biorex-2) }\end{array}$ & $\begin{array}{l}\text { Azotobacter chroococcum: } \\
\text { Azospirillum lipoferum; } \\
\text { Pseudomonas putida. }\end{array}$ & $2 \times 10^{10}$ & $\begin{array}{c}10 \mathrm{~L} / \mathrm{ha}, \\
0.375 \mathrm{ml} / \text { plants }\end{array}$ \\
\hline $\mathrm{BE}+\mathrm{BR} 2$ & Combination of 2 products & $1.25 \times 10^{10}+1 \times 10^{10}$ & $0,2+0,375 \mathrm{ml} /$ plants \\
\hline
\end{tabular}

Most probable number (MPN) method of sporeforming bacteria in soil capable of growing in nutrient broth (meat extract $3 \mathrm{~g}$; peptone $5 \mathrm{~g}$; $\mathrm{pH} 7 \pm 0.2$ ) (Marshall, 1993; Downes and Ito, 2001) was used by a microplate method. 10-fold serial soil dilutions were made from $10^{-1}$ to $10^{-8}$ dilutions as described (Libisch et al., 2010). Average soil samples were collected at the $10^{\text {th }}$ and $14^{\text {th }}$ weeks of tomato growth, with the highest suggested microbial activity in soil-plant system (Biró et al., 2000). From each samples and from each dilution three parallel $20 \mu \mathrm{l}$ aliquots were transferred to sterile polystyrene 96 -well microplates, after 10 minutes stay in water bath at $80{ }^{\circ} \mathrm{C}$ to kill the vegetative cells. Microplates were incubated at $28^{\circ} \mathrm{C}$ for 1 week. The plates were tested after that for growth using the respiration indicator iodo-nitro-tetrazolium violet (INT) (Sigma-Aldrich) (Johnsen and Henriksen, 2009). 50 $\mu 1$ INT solution (3g/L INT dissolved in water) was added to each well, and the plates were incubated overnight at $28^{\circ} \mathrm{C}$. Metabolically active bacteria reduce INT to the corresponding formazan forming a purple precipitate. The number of growth-positive wells at each dilution was determined 
by visual inspection of the plates. The statistical method of Cochran was applied to calculate MPN values using the MPN calculator VB6 (Cochran, 1950). One-way Anova Tukey test with $\log$ MPN values and standard $\log M P N$ errors was used to determine whether MPN values of various pot experiment and field experiment soil samples were not significantly different at the $95 \%$ confidence level $(<0.05)$ (Mukherjee et al., 2006; Vladar et al., 2008).

\section{Fruit quality assessments}

Sugars are the major soluble solids in tomato fruit juice. Soluble solids concentration (Brix or TSS) can be determined in a small sample of fruit juice using a hand held refractometer. Total soluble solid content (TSS) of tomato fruits was determined by Atago ${ }^{\circledR}$ PAL-3 refractometer device (Cavalcanti et al., 2013). The fruits (skins and fruit-pulp) were homogenized with a blender and homogenates were stored at $-25{ }^{\circ} \mathrm{C}$ until analysis. After hawing $2 \mathrm{~g}$ from each fruit puree samples were diluted in $2 \mathrm{ml}$ deionized water, shake for 1 hour in dark and centrifuged for $10 \mathrm{~min}$ at $10000 \mathrm{rpm}$ (Hettich Mikro 22R). One ml supernatant was then pipetted off and filtered through a 0.45- $\mu \mathrm{m}$ MILLEX $^{\circledR}$-HV Syringe Driven Filter Unit (SLHV 013 NL, PVDF Durapore), purchased from Millipore Co. (Bedford, MA, USA). WATERS High Performance Liquid Chromatograph (HPLC, Waters Co., 34 Maple Street, Milford, MA, USA) equipped with 2487 Dual $\lambda$ Absorbance Detector (for determination of organic acids), 2414 Refractive Index Detector (for the determination of sugars) 1525 Binary HPLC Pump, In-Line Degasser, Column Thermostat (set at $40{ }^{\circ} \mathrm{C}$ ) and 717 plus Autosampler controlled with EMPOWER ${ }^{\mathrm{TM}} 2$ software was used for HPLC analysis. For separation of organic acids Shodex KC-811 column $(8 \mathrm{~mm} \times 300 \mathrm{~mm})$ with Shodex RSpak KC-G guard column were used. Mobile phase was a $0.1 \%$ aqueous solution of phosphoric acid. Flow rate was adjusted to $1 \mathrm{ml} . \mathrm{min}^{-1}$, giving a pressure of $600 \pm 25$ psi on the column at $40{ }^{\circ} \mathrm{C}$. The volume injected on the column was $20 \mu \mathrm{l}$, the detection time was adjusted to $20 \mathrm{~min}$. Detection was carried out at analytical wavelength of $220 \mathrm{~nm}$. Retention times (in min.) of the standards were 7.19 for citric- and 9.10 for malic acids. For separation of sugars a Sugar-PakTM column was used placed in a thermostat at 90 ${ }^{\circ} \mathrm{C}$. The mobile phase was a $0.0001 \mathrm{M}$ aqueous solution of Ca-EDTA. Flow rate was 0.5

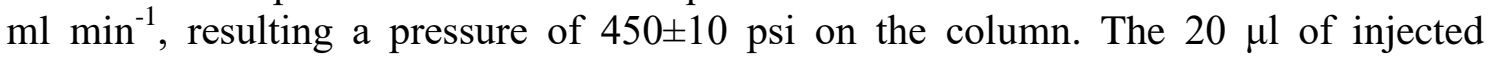
volume was used, detection took $30 \mathrm{~min}$. for each sample. Retention times of standards were 8.32 for sucrose, 10.93 for glucose and 11.77 for fructose. Two replicates were used. Concentrations were calculated from areas of corresponding peaks and expressed in $\mathrm{mg} \cdot 100^{-1} \mathrm{~g}$.

\section{Statistical analysis}

For evaluation of the results one-way ANOVA test was applied. Normality assumption was proven by Kolmogorov-Smirnov test $(\mathrm{p}>0.05 ; \mathrm{p}=0.200)$ or ShapiroWilk test $(\mathrm{p}>0.05)$ and the homogeneity of variances was checked by Levene's test ( $>>0.05)$. As the estimation was proven we applied Tukey HSD post hoc test. If it was not proven the Games-Howell post hoc test was applied. Pearson correlation analysis was used to estimate the interrelation among soil and tomato fruit quality parameters. The analysis is appropriate to know how the involved and studied variables are related to each other. Results are presented in Figures and in Tables. 


\section{Results}

\section{Soil parameters with bioeffector application}

\section{MPN counts of sporeforming bacteria}

Fig $1 a$ is showing the most probable number (MPN) of cultivable microorganisms in the soils, treated or non-treated by bioeffectors in the pot experiments. According to the result of total plate count, normality assumption was proven by the Shapiro-Wilk test $\left(\mathrm{p}>0.05 ; \mathrm{p}_{1}=0.715 ; \mathrm{p}_{2}=0.883\right)$ and the homogeneity of variances was checked by Levene's test. As the assumption was proven, $[\mathrm{F}(7 ; 32)=2.151 ; \mathrm{p} 1>0.05 ; \mathrm{p}=0.066]$ we applied Tukey HSD post hoc test. Differences among the treatments were not appeared significantly. However, it is apparent that the number $(\operatorname{logMPN})$ of microorganisms in the BE-treated soils was enhanced tendentiously from April to July in the pot experiment (Fig. Ia).

Among the natural field conditions Fig $1 b$ is showing the most probable number of microorganisms in the soil of the field experiments after 8 (July) and 14 (September) weeks of growth. According to total plate count results, normality was proven by Shapiro-Wilk test $(\mathrm{p}>0.05 ; \mathrm{p} 1=0.715 ; \mathrm{p} 2=0.883)$ and homogeneity of variances was checked by Levene's test. The assumption was proven, therefore we used Tukey HSD post hoc test $\left[\mathrm{F}_{\text {July }}(7 ; 8)=0.015 ; \mathrm{F}_{\text {Sept }}(7 ; 19)=0.057 ; \mathrm{p}>0.05\right]$. Differences among the treatments were not appeared significantly either any growing conditions. In case of pot experiment the number of microorganisms in BE-treated soils were increased but the same was not proven among the field conditions, at the studied periods. No differences among the various bioeffector treatments could be found at the sampled time (Fig. 1 b).
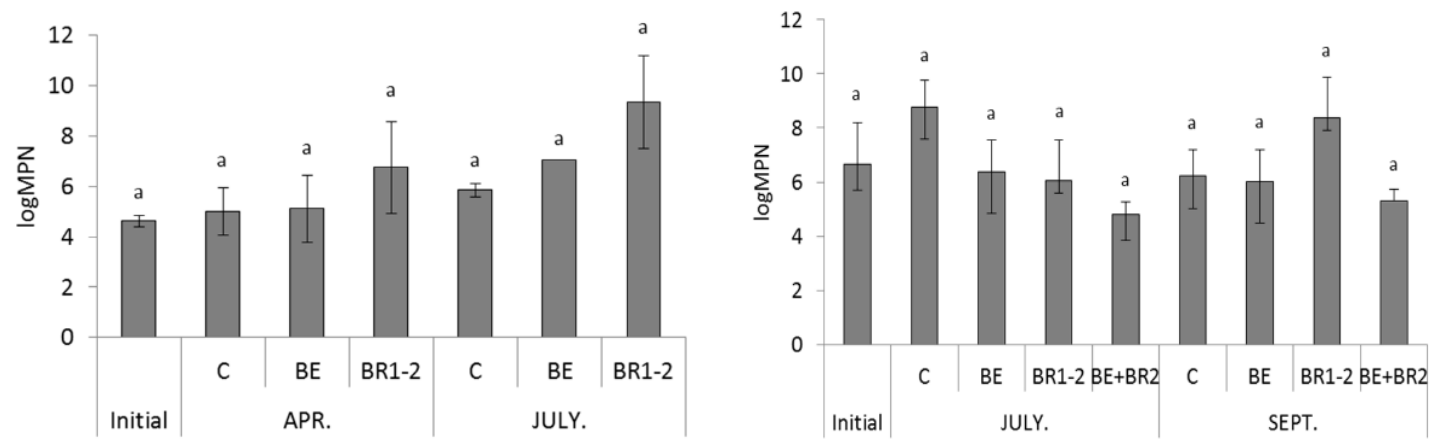

Figure 1a, b. Most probable number of microorganisms (logMPN) in soils treated or not by various bioeffector products $(\boldsymbol{a})$ and $(\boldsymbol{b})$. Results in pots and in field, respectively $(n=4)$

\section{Soil-available phosphorus}

Prior to the pot-trial a preliminary soil analysis was performed in soils, originating from the experimental field of Soroksár (Hungary), the site of the field tests on the same year. A specific focus was given for the availability of phosphor (P) doses, due to the fact, that used bioeffector products were predicted of containing mainly the specific Pmobilizing microorganisms. Among the macro elements, examined, phosphor content was found to be increased mainly in the pot experiment. Treatment with the presumably phosphorous-mobilizer Bacillus (BE, BR1) strains could increase the available Pcontent in the soil significantly (Fig. 2a). 
Among field conditions it was also examined that phosphorus mobilizer Bacillus (BE, BR1, BR2) strains could increase the available P-content in soils. Among treated and non-treated soils, however, no significant differences were recorded $[\mathrm{F}(3 ; 8)=$ $2.269 ; \mathrm{p}=0.071]($ Fig. $2 b)$.
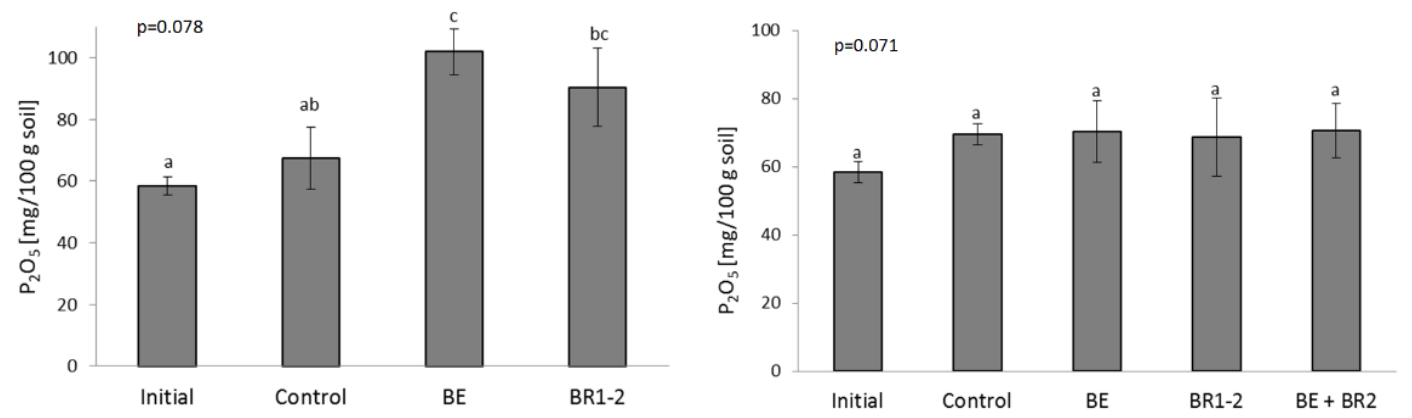

Figure 2a, b. Phosphorous, $\mathrm{P}_{2} \mathrm{O}_{5}$ content of soils after (a) 10- (in pots) and (b) 14 weeks (in field) growth of tomato $(n=4)$

\section{Fruit quality parameters with bioeffector application}

Total soluble solids of tomato fruits

Tomato's fruit quality parameters were examined, by assessing the total soluble solid content (TSS). In case of pot experiment TSS value was significantly higher through the effect of used BE industrial product; while in case of BR1-2 treatments TSS value was significantly lower compared to the control. Post hoc comparisons using Games-Howell test indicated, that the mean score of $\mathrm{BE}(\mathrm{M}=9.00 ; \mathrm{SD}=0.608)$ and the $\mathrm{BR} 1-2$ treatment $(\mathrm{M}=5.2 ; \mathrm{SD}=0.122)$ were significantly different from the control $(\mathrm{M}=6.62 ; \mathrm{SD}=0.16)$ (Fig. 3a).
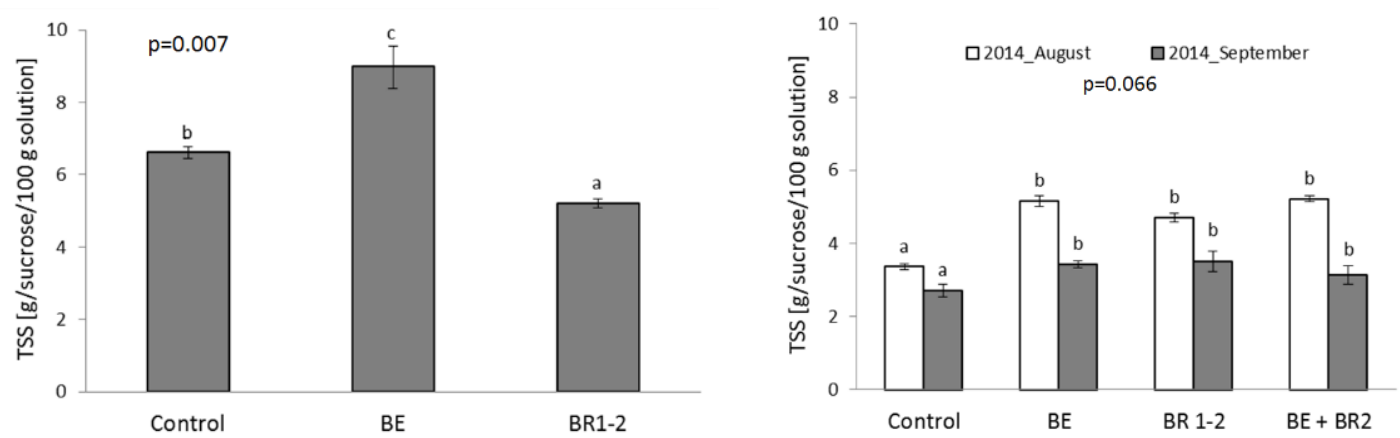

Figure $3 \boldsymbol{a}, \boldsymbol{b}$. Total soluble solid (TSS) content of tomato fruits after (a) 10 weeks of growth (in pots) and (b) as harvested after 10- (in August) and 14- (in September) weeks of growth (field experiment) $(n=4)$

Among field condition beside the single BE treatment, combined effect of bioeffectors (BR1-2 and BE+BR2) was examined. In field the tomato fruits were harvested two times during the vegetation period (after 10 weeks, in August 2014, and after 14 weeks in September 2014). The fruit quality analysis was carried out on average samples after performing both harvests. In case of the field experiment TSS 
value of fruits from the treated plots were significantly higher than the control at both harvests. Post hoc comparisons using the Tukey HSD test indicated that the mean score of $\mathrm{BE}(\mathrm{M}=5.16, \mathrm{SD}=0.15), \mathrm{BR} 1-2$ treatment $(\mathrm{M}=4.7 ; \mathrm{SD}=0.02)$ and the $\mathrm{BE} 3+\mathrm{BR} 2$ combination $(\mathrm{M}=5.22 ; \mathrm{SD}=0.08)$ were significantly different than the control $(\mathrm{M}=3.36$; $\mathrm{SD}=0.089)$. In September the TSS value decreased but the differences have remained similar (Fig. 3b).

\section{Sugar and organic acid content of tomato fruits}

Among inside fruit quality parameters some of the sugar- (glucose, fructose) and the organic acids (citric-, malic-) components were assessed by high performance liquid chromatography (HPLC) both in pots and in field experiments. In comparison with total soluble solid (TSS) values, similar result appeared with the HPLC-measured sugar components, although those results were found to be lower. Regarding the sugar content in the pot experiment there were no significant differences found in comparison with the control but differences were significantly supported between the two treated groups. TSS value was found to correlate slightly with the concentration of sugar component measured by HPLC. Normality assumption was proven by Kolmogorov-Smirnov test $(\mathrm{p}>0.05 ; \mathrm{p} 1=0.200 ; \mathrm{p} 2=0.117)$ and the homogeneity of variances was estimated by Levene's test As the assumption was not proven $[\mathrm{F} 1=\mathrm{F} 2(3 ; 4)=0.005 ; \mathrm{p}<0.05]$ a GamesHowell post hoc test was applied (Fig. 4a).

The organic acids (citric- and malic) were also assessed by HPLC analysis. Regarding the pot experiment the organic acid content was significantly higher in case of control $(\mathrm{M}=565.79 ; \mathrm{SD}=3.46)$ than the $\mathrm{BE}(\mathrm{M}=525.39 ; \mathrm{SD}=2.79)$ and $\mathrm{BR} 1-2$ treatments $(\mathrm{M}=261.03 ; \mathrm{SD}=3.25)($ Fig. 4b).
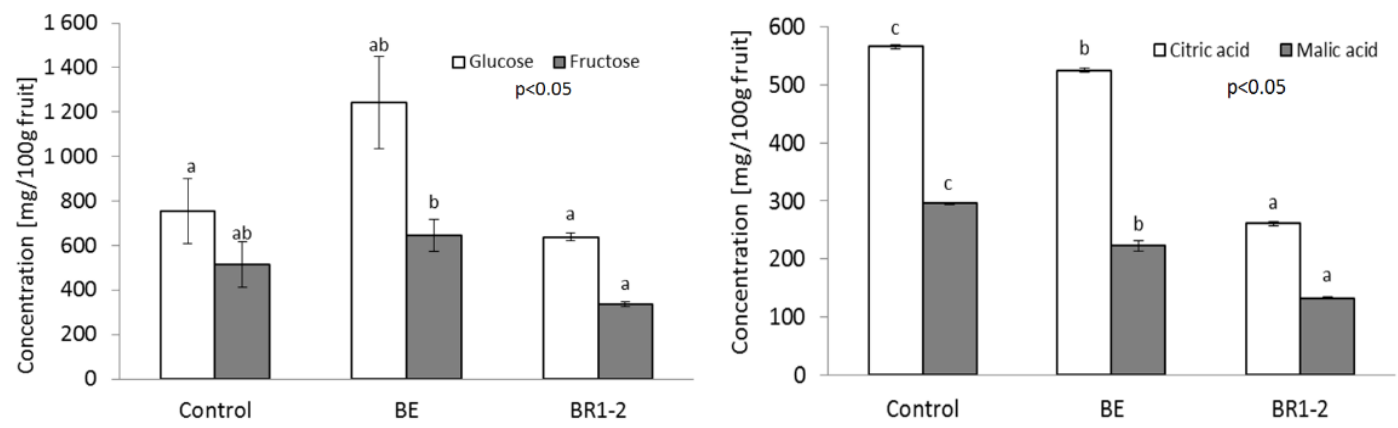

Figure 4a, b. Sugar (glucose and fructose) (a) and organic acid (citric-, malic-) (b) content of tomato fruits after 10 weeks of growth in pot experiment $(n=4)$

In case of the sugar content in tomato fruits from the field experiment, no significant differences were found in fructose and in glucose contents when single BE treatment was used. When two harvesting periods were compared, the same results were achieved, so no significant differences were found in the sugar concentration. Both normality assumption was proven by Kolmogorov-Smirnov test ( $p>0.05 ; p_{\text {Aug }}=0.200 ; p_{\text {Sept }}=0.117$ ) and the homogeneity of variances was estimated by Levene's test. As the assumption was not proven $\left[\mathrm{F}_{\text {Aug }}=\mathrm{F}_{\text {Sept }}(3 ; 4)=0.005 ; \mathrm{p}<0.05\right]$ a Games-Howell post hoc test was applied. Post hoc comparisons using the Games-Howell test indicated that the mean score of BE, BR1-2 treatments, and the BE+BR2 combination were not significantly different than the control (Fig. 4a). 
The organic acids (citric- and malic) were also assessed by HPLC analysis. In the field experiment two sampling periods and measurement of the organic acids were applied. In September there was an increasing amount of citric acid in tomato fruits, grown in the bioeffector treated soil. The same only tendentiously was supported for malic acid content (Fig. 5b).
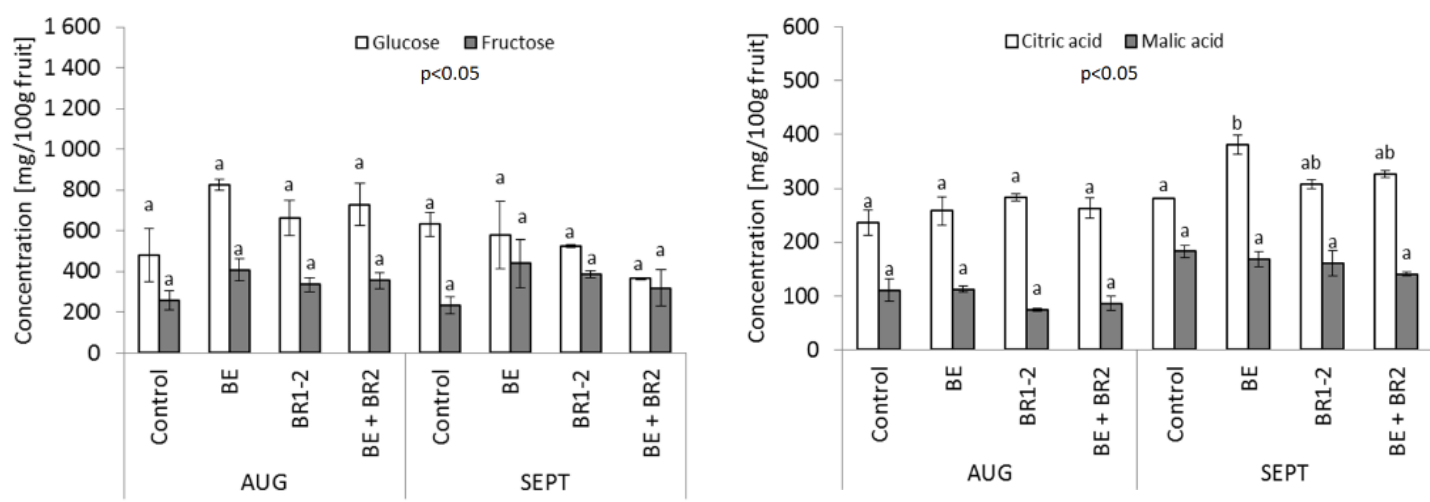

Figure 5a, b. Sugar (glucose and fructose) (a) and organic acid (citric-, malic-) (b) concentration of tomato fruits after 10 (August) or 14 (September) weeks of growth in field experiment $(n=4)$

\section{Correlation among soil characteristics and tomato fruit quality parameters}

Correlation analysis was performed among total cultivable sporeforming microorganisms (Bacillus sp.), estimated by MPN (Most Probable Number) method and some of the tomato fruit quality parameters both at pot- and at field experiments.

Correlation results of MPN, measured TSS values and estimated inside fruit quality parameters are shown in Table 3 and Table 4. Interrelation of inside fruit quality with the used biofertilizer application was found to be greater in pot experiment, in comparison with the field experiment with more variable environmental condition.

Results of pot and field experiments are summarized in Appendix 1. Measured data of microbial soil and fruit quality parameters are detailed, as the average of 4 replicates, with the standard errors.

Table 3. Correlation among soil microbial abundance of sporeforming bacteria $(M P N)$, the total soluble sugars (TSS) and inside fruit quality parameters, soluble sugars (glucose, fructose) and organic acids (citric-, malic-) in tomato fruits, grown in pot experiment $(n=4)$

\begin{tabular}{c|c|c|c|c|c|c}
\hline \multicolumn{7}{c}{ Correlation values (pot experiment) } \\
\hline & MPN & TSS & Glucose & Fructose & Citric-acid & Malic-acid \\
\hline MPN & 1 & $\mathbf{0 , 7 8 8}^{* *}$ & 0,666 & 0,643 & 0,473 & 0,261 \\
TSS & $\mathbf{0 , 7 8 8}^{* *}$ & 1 & $\mathbf{0 , 9 4 5}^{* *}$ & $\mathbf{0 , 9 3 6 * *}^{* *}$ & $\mathbf{0 , 7 0 8}^{*}$ & 0,432 \\
Glucose & 0,666 & $\mathbf{0 , 9 4 5}^{* *}$ & 1 & $\mathbf{0 , 9 1 0}^{* *}$ & 0,520 & 0,213 \\
Fructose & 0,643 & $\mathbf{0 , 9 3 6}^{* *}$ & $\mathbf{0 , 9 1 0}$ & 1 & $\mathbf{0 , 8 0 4}^{* *}$ & 0,582 \\
Citric-acid & 0,473 & $\mathbf{0 , 7 0 8}^{* *}$ & 0,520 & $\mathbf{0 , 8 0 4}^{* *}$ & 1 & $\mathbf{0 , 9 4 1}^{* *}$ \\
Malic-acid & 0,261 & 0,432 & 0,213 & 0,582 & $\mathbf{0 , 9 4 1}^{* *}$ & 1 \\
\hline
\end{tabular}

**. Correlation is significant at the 0.01 level; *. Correlation is significant at the 0.05 level. 
Table 4. Correlation among soil microbial abundance of sporeforming bacteria (MPN), the total soluble sugars (TSS) and inside fruit quality parameters, soluble sugars (glucose, fructose) and organic acids (citric-, maleic-) in tomato fruits, grown among field condition $(n=4)$

\begin{tabular}{c|c|c|c|c|c|c}
\hline \multicolumn{7}{c}{ Correlation values (field experiment) } \\
\hline & MPN & TSS & Glucose & Fructose & Citric-acid & Malic-acid \\
\hline MPN & 1 & 0,192 & $-0,459$ & $-0,490$ & 0,423 & $-0,463$ \\
TSS & 0,192 & 1 & 0,015 & $-0,160$ & $\mathbf{0 , 8 8 0}$ & $\mathbf{- 0 , 5 8 6}^{* *}$ \\
Glucose & $-0,459$ & 0,015 & 1 & $\mathbf{0 , 9 6 5}$ & 0,276 & 0,297 \\
Fructose & $-0,490$ & $-0,160$ & $\mathbf{0 , 9 6 5}$ & 1 & 0,113 & 0,431 \\
Citrit-acid & 0,423 & $\mathbf{0 , 8 8 0}^{* *}$ & 0,276 & 0,113 & 1 & $-0,222$ \\
Malic-acid & $-0,463$ & $\mathbf{- 0 , 5 8 6}^{*}$ & 0,297 & 0,431 & $-0,222$ & 1 \\
\hline
\end{tabular}

**Correlation is significant at the 0.01 level; *. Correlation is significant at the 0.05 level.

\section{Discussion}

"Biofector" is an integrated international project with the aim to reduce input of mineral fertilizers in European agriculture by development of specifically adapted bioeffector microorganisms (BEs) to improve the efficiency of alternative fertilization strategies, such as organic and low-input farming, use of fertilizers based on waste recycling products and fertilizer placement technologies. Bioeffectors addressed comprise fungal and bacterial strains (e.g. Bacillus, Trichoderma, Pseudomonas etc.) with well-characterized root growth promoting and nutrient solubilizing potential. In Biofector international project one of the test plants is tomato, which is important in many ways in human consumption. Significant industrial and commercial use is known, exceeding all of the vegetables in terms of both cultivation and consumption in World. The aim of Biofector research project is the development of viable alternatives to conventional mineral fertilization, and contribution to a more efficient management of non-renewable resources of mineral nutrients, energy and water, to preserve soil fertility and to counteract the adverse environmental impact of agricultural production. Our study is part of the above mentioned research.

Tomato is very sensitive to the $\mathrm{P}$ supply. It is required relatively high amount of phosphorus, especially at the beginning of its growth (Schmidt et al., 2010). For this reason, some of the marketed bioeffector products were used in this study, which are known to solubilize and mobilize the highly available phosphorus content in the soil. The general use of Bacillus spp. strains as P-mobilizing microorganisms are also supported by the fact that those microbes can survive in the soils among several, even at the most serious environmental stress conditions. Due to its spore forming ability the cells of the Bacillus spp. can survive long in the soils and at any potential environmental conditions. It is why the individual species and Bacillus spp. genus are considered as one of the microbial groups, with specific food-quality and safety importance (Beczner et al., 2004; Dudás et al., 2014; Kocsis and Biró, 2015). Among the marketed products, which are containing spore forming bacteria there were single and combined inoculation treatments used in this study. It was hypothesized that the more types of bacteria, including more than one particular species could produce better performance for the plant growth promotion ability. This idea was already supported by several authors of using different combinations of bacteria or fungal-bacterial consortium, with an uppermost importance of such systems in polluted or environmentally stressed 
ecosystems (Kloepper et al., 1989; Biró et al., 1993; Mantelin and Touraine, 2004; Vivas et al., 2006). Among sustainable agricultural practice the synergism of symbiont type of microbes is also demonstrated between arbuscular mycorrhiza fungi and the nitrogen-fixing bacteria. The behaviour of microbes in a consortium is dependent on several environmental factors. It has been reported, that even a beneficial symbiosis is diminished in a short time of periods when the environmental condition, such as the drought, high temperature or reduction of light intensity or heavy metals toxicity become non-tolerable to the macro- and micro-symbionts (the higher plants and the microbes) (Biró et al., 2000, 2015; Füzy et al., 2014). In case of the microbes are tolerable to severe environmental stress-condition, the symbiosis with a joint strategy might be helpful, finally resulting the better survival and growth of host-plants.

The abundance of inoculated microorganisms was followed by the most probable number (MPN) method. The quantity of cultivable spore-forming microbes were estimated, by preliminary kill of the non-spore-bearing vegetative cells from the soilsuspension. Although the presence or absence of those inoculated microorganisms was assessed only occasionally at the beginning and at 2-times during the vegetation periods, there were not greater abundance recorded as the total countable number in the tomato rhizosphere. This result indicates the potential of fast microbial changes in the rhizosphere and the interrelation among microbial colonization with plant growth parameters. Similar conclusion was made by Biró et al. (2015) who found that this effects can be highly dependent on the soil quality, the nutrient content of soils, more particularly focusing on the soil available nutrients during plant growth. On the basis of Kocsis et al. (2015) this type of slightly hummus sandy soil are low in available nutrients and in specific microbes. Significantly increase the microbial abundance is necessary to use soil improvers (e.g. biochar) or organic fertilizer, compost application, which might enhance soil microbial status in one step. We found only in the pot experiment that the abundance of microorganisms is increasing with the plant age. The importance of microbial inoculation is highlighted at early seedling status, when the PGR hormone-effect of inoculated microbes might enhance root-volume, indirectly improve water- and nutrient-uptake of plants (Yang et al., 2009; Biró et al., 2000; Choudry et al., 2015). The connection of microbial presence and activity with plant-necessity was already demonstrated among serious environmental stress conditions in several previous publications (Vivas et al., 2006; Domonkos et al., 2010; Panwar et al., 2011).

Testing the MPN abundance of specific sporeforming microorganisms in the tomato plant rhizosphere, differences among the used treatments were not found significantly in our study. It was apparent, however that the number $(\log M P N)$ of studied microbes in the BE treated soils was enhanced tendentiously with plant age (from April to July) in the pot experiment. It was also demonstrated in this study, that the abundance was found parallel with the available phosphorus concentrations in the soil. In connection with this finding Fekete et al. (2011) found, that more organic P can enhance the alkaline phosphatase activities, which finally increase the P-availability in the soil. The alkaline phosphatase is mainly produced by the soil microorganisms and the extent of its synthesis and excretion of it can be coupled to the microbial activity and/or the population size, as it was shown by Kaleeswari (2007) and Garg and Bahl (2008). Due to the presence of BE Bacillus amyloliquefaciens FZB42 an increased phosphorus content was found in the treated pots. 
Regarding the size and number of fruits there was also an increase in treatment $\mathrm{BE}$ and BR1-2 in the pot experiment (data not shown). Richardson et al. (2001) and Idriss et al. (2002) made a similar finding in their experiments in laboratory and field conditions with the same Bacillus amyloliquefaciens species. They found that improved phosphorus nutrition is achievable by mobilization of phosphorus fixed as insoluble inorganic polyphosphates which accounts for $20-50 \%$ of the total soil organic phosphorus. It is generally accepted that higher microbial counts can result higher nutrient availability in soil. Contrarily, in case of the combined treatments, where beside the Bacillus spp. strains some other microorganisms, as the Nitrogen-fixing Azospirillum and Azotobacter furthermore the siderophore-producing Pseudomonas bacteria (BE+BR-2) were given, no further improved growth parameters were recorded on tomato.

Considering the fruit quality there are also several study of showing the importance of biofertilizer application. According to Bruulsema et al. (2004), phosphorous fertilization is a key component in the metabolism and regulation of several pathways involved in the biosynthesis of secondary plant metabolites. Many of those materials are biologically active compounds. P may increase the level of some acids such as ascorbic acid, although interaction with climatic factors and the growing season growing area may occur. The high level of citric acid concentration was found at a high level of phosphorus concentration by Di Cesare et al. (2010). Tóth et al. (2007), Oke et al. (2005) studied the effect of P fertilizer on the quality of tomato under field conditions for three consecutive years, by evaluating the $\mathrm{pH}$, the acidity, the lycopene, the vitamin $\mathrm{C}$ content and also the flavour volatiles. They noted that the influence of $\mathrm{P}$ application on several of the quality parameters mentioned above was marginal, while climatic conditions had a more predominant effect. Organic acids and sugar comprise the majority of the total dry matter content of tomatoes (Malundo et al., 1999). The "reducing type" of sugars and organic acids are significant components of fruits, determining the sweet- and the sour taste of the tomatoes, respectively. Their concentration may also affect flavours acceptability (Salles et al., 2003). Tomato fruits harvested at the same time from the bioeffector-treated plots had a more balanced acidsugar ratio and the control had higher level of organic acid concentration. The wellbalanced acid-sugar ratio appreciably increases the food quality and tasty value of the tomato fruits.

On the bases of this study we found that phosphorus mobilizer microorganisms can be successfully used as bio-fertilizers in ecological farming systems, since through applying them soluble phosphorus of the soil might be increased under certain environmental conditions. Phosphorus content of the soil was higher as a result of the used bioeffector inoculation, presumably capable for phosphorus mobilization. As a consequence, the nutritional and food quality and tasty value of tomato fruits (the acidTSS ratio) have changed to a more favourable, tasteful direction. A tastier, more marketable food was produced by an ecological organic way. Governed by the principles of sustainable farming methods, the application of artificial agrochemicals can be reduced, including also the inorganic phosphorus fertilizer application. Ecofriendly, natural bio-fertilizers and combined bioeffective solutions might play important role in the sustainable agri-/horticultural practices.

Acknowledgements. The project was supported by Eu-Kp7 Biofector (www.biofector.info) „Resource preservation by application of bioeffectors in European crop production" (GA 312117) and the PIAC_13 1-2013-0274 Hungarian "Biochar-EM" projects. Support for providing the bioeffector products are highly acknowledged for the producers. 


\section{REFERENCES}

[1] Baldwin, E. A., Nisperos-Carriedo, M. O., Baker, R., Scott, J. W. (1991): Quantitative analysis of flavour parameters in six parameters in six Florida Tomato cultivars (Lycopersicon esculentum Mill). - J. Agric. Food Chem. 39:1135-1140.

[2] Bashan, Y., Kamnev, A. A., Luz, E. (2013): Tricalcium-phosphate is inappropriate as an universal selection factor for isolating and testing phosphate-solubilizing bacteria that enhance plant growth: a proposal for an alternative procedure. - Biofertil. Soils 49:465479.

[3] Beczner, J., Janko, Sz., Biró, B. (2004): Occurence of microbes of food safety importance in soils treated with sewage sludge. - Acta Microbiol. Immunol. Hung. 51:216-217.

[4] Béni, Á., Lajtha, K., Kozma, J., Fekete, I. (2017): Application of a Stir Bar Sorptive Extraction sample preparation method with HPLC for soil fungal biomass determination in soils from a detrital manipulation study. - J. Microbiol. Meth. (in press) doi: 10.1016/j.mimet.2017.02.009

[5] Béni, A., Sóki, E., Lajtha, K., Fekete, I. (2014): An optimized HPLC method for soil fungal biomass determination and its application to a detritus manipulation study. - J. Microb. Meth. 103:124-130.

[6] Biró, B., Vörös, I., Köves-Péchy, K., Szegi, J. (1993): Symbiont effect of Rhizobium bacteria and VAM fungi on Pisum sativum in recultivated mine spoils. - Geomicrobiol. J. 11: 275-284.

[7] Biró, B., Kádár, I., Lampis, S., Gullner, G., Kőmíves, T. (2012): Inside and outside rhizosphere parameters and dose-dependent stress alleviation at some chronic metal exposures. - Acta Phytopathol. Entomol. Hung. 47:373-384.

[8] Biró, B., Szalai, Z., Dudás, A., Gáspár, T., Wass-Matics, H., Kotroczó, Zs. (2015): Single and tripartite biofectors for tomato (var. Mobil) upscaled from pots to plots. Rhizosphere 4 conference, "Stretching the Interface of Life". - Maastricht, the Netherlands, 21-25 June 2015.

[9] Biró, B., Köves-Péchy, K., Vörös, I., Takács, T., Eggenberg, P., Strasser, R. J. (2000): Interrelation between Azospirillum and Rhizobium nitrogen-fixers and arbuscular mycorrhizal fungi in the rhizosphere of alfalfa at sterile, AMF-free or normal soil conditions. - J. Appl. Soil Ecol. 15:159-168.

[10] Bruulsema, T. W., Paliyath, G., Schofield, A., Oke, M. (2004): Phosphorous and phytochemicals. - Better Crops 88:6.

[11] Caldeira, A. T., Feio, S. S., Arteiro, J. M. S., Coelho, A. V., Roseiro, J. C. (2008): Environmental dynamics of Bacillus amyloliquefaciens CCMI 1051 antifungal activity under different nitrogen patterns. - J. Appl. Microbiol. 104:808-816.

[12] Carvalhais, L. C., Dennis, P. G., Fan, B., Fedoseyenko, D., Kierul, K., Becker, A., von Wiren, N., Borriss, R. (2013): Linking plant nutritional status to plant-microbe interactions. - PLoS ONE. 8:e68555.

[13] Cavalcanti, A. L., de Oliveira, K. F., Xavier, A. F., Pinto, D. S., Vieira, F. F. (2013): Evaluation of total soluble solids content (TSSC) and endogenous $\mathrm{pH}$ in antimicrobials of pediatric use. - Ind. J. Dental Res. 24:498-501.

[14] Choudry, S. P., Hartmann, A., Gao, X., Borriss, R. (2015): Biocontrol mechanism by root-associated Bacillus amyloliquefaciens FZB42 - a review. - Front Microbiol. 8 (6):780. doi: 10.3389/fmicb.2015.00780.

[15] Cochran, W. G. (1950): Estimation of bacterial densities by means of the "Most Probable Number". - Biometrics 6: 105-116.

[16] Davies, J. N., Hobson, G. E. (1981): The constituents of tomato fruit - the influence of environment, nutrition, and genotype. - Crit. Rev. Food Sci. Technol. 15:205-280.

[17] Den Hollander, N. G., Bastiaans, L., Kropff, M. J. (2007): Clover as a cover-crop for weed suppression in an intercropping design. Characteristics of several clovers species. Eur. J. Agron. 26:92-103. 
[18] Devi, M., Dhaliwal, M. S., Kaur, A., Gosal. S. S. (2008): Effect of growth regulators on in vitro morphogenetic response of tomato. - Indian J. Biotechnol. 7:526-530.

[19] Di Cesare, L. F., Migliori, C., Viscardi, D., Parisi, M. (2010): Quality of tomato fertilized with nitrogen and phosphorous. - Italian J. Food Sci. 22:186-191.

[20] Diamantidis, G., Effosse, A., Potier, P., Bally, R. (2000): Purification and characterization of the first bacterial laccase in the rhizospheric bacterium Azospirillum lipoferum. - Soil Biol. Biochem. 32:919-927.

[21] Domonkos, M., Schmidt, B., Libisch, B., Polgári, M., Biró, B. (2010): Growth and mycorrhizal colonization of four grasses in a Mn-amended low quality sandy soil. - Res. J. Agricult. Sci. 44:44-50.

[22] Downes, F. P., Ito, K. (2001): Compendium of methods for the microbiological examination of foods, $4^{\text {th }}$ ed. - American Public Health Association, Washington, D.C. 473-81.

[23] Dudás, A., Gáspár, T., Kotroczó, Zs., Győri, A., Wass-Matics, H., Keöd, Á., Végvári, Gy., Biró, B. (2014): Spore-forming Bacillus inoculums affecting tomato growth and yields. - Economica 7:169-174. (in Hungarian)

[24] Egner, H., Riehm, H., Domingo, W. R. (1960): Untersuchungen über die chemische Bodenanalyse als Grundlage für die Beurteilung des Nahrstoffzustandes der Boden, II: Chemische Extractionsmetoden zu Phosphor und Kaliumbestimmung. - Kungliga Lantbrukshügskolans Annaler 26:199-215.

[25] Fekete, I., Lajtha, K., Kotroczó, Zs., Várbíró, G., Varga, Cs., Tóth, J. A., Demeter, I., Veperdi, G., Berki, I. (2017): Long term effects of climate change on carbon storage and tree species composition in a dry deciduous forest. - Glob. Change Biol. (in press) doi: 10.1111/gcb.13669

[26] Fekete, I., Kotroczó, Zs., Varga, Cs., Nagy, P. T., Várbíró, G., Bowden, R. D., Tóth, J. A., Lajtha, K. (2014): Alterations in forest detritus inputs influence soil carbon concentration and soil respiration in a Central-European deciduous forest. - Soil Biol. Biochem. 74:106-114.

[27] Fekete I, Varga, Cs., Kotroczó, Zs., Tóth, J. A., Várbíró, G. (2011): The relation between various detritus inputs and soil enzyme activities in a Central European deciduous forest. - Geoderma 167-168:15-21.

[28] Fekete, I., Varga, Cs., Halász, J., Krakomperger, Zs., Krausz, E. (2008): Study of litter decomposition intensity in litter manipulative trials in Síkfökút Cambisols. - Cer. Res. Comm. 36:1779-1782.

[29] FIBL (Research Institute of Organic Agriculture). Organic Farming in Europe. Provisional Statistics (2001). Available at Organic-Europe, www.organiceurope.net/europe_eu.

[30] Füzy, A., Bothe, H., Molnár, E., Biró, B. (2014): Mycorrhizal symbiosis affects on growth of chalk false-brome (Brachypodium pinnatum) are dependent on the environmental light regime. - J. Plant Physiology 171: 1-6.

[31] Garg, S., Bahl, G. S. (2008): Phosphorus availability to maize as influenced by organic manures and fertilizer P associated phosphatase activity in soils Bioresour. - Technol. 99:5773-5777.

[32] Glendining, M. J., Dailey, A. G., Williams, A. G., van Evert, F. K., Goulding, K. W. T., Whitmore, A. P. (2009): Is it possible to increase the sustainability of arable and ruminant agriculture by reducing inputs? - Agric. System. 99:117-125.

[33] Glick, B.R, Todorovic, B., Czarny, J., Cheng, Z., Duan, J., McConkey, B. (2007): Promotion of plant-growth by bacterial ACC deaminase. - Crit. Rev. Plant Science. 6:227-242.

[34] Hariprasad, P., Niranjana, S. R. (2009): Isolation and characterization of phosphate solubilizing rhizobacteria to improve plant health of tomato. - Pl. Soil. 316:13-24.

[35] Hayat, R., Ali, S., Amara, U., Khalid, R., Ahmed, I. (2010): Soil beneficial bacteria and their role in plant growth promotion: a review. - Annals Microbiol. 60:579-598. 
[36] Herrera, F., Castillo, J. E., Chica, A. F., Bellido, L. L. (2008): Use of municipal solid waste compost (MSWC) as a growing medium in the nursery production of tomato plants. - Bioresour. Technol. 99:287-296.

[37] Hesammi E., Farshidi, A., Talebi, A. B. J., Chrazi, C. (2014): Advances in Environmental Biology Organic Farming and Sustainable Farming in Ecological Farming Systems in Iran. - Adv. Environm. Biol. 8:461-466.

[38] Idriss, E.E., Makarewicz, O., Farouk, A., Rosner, K., Greiner, R., Bochow, H., Richter, T., Borriss, R. (2002): Extracellular phytase activity of Bacillus amyloliquefaciens FZB45 contributes to its plant-growth-promoting effect. - Microbiol. 148:2097-2109.

[39] Johnsen, A.R., Henriksen, S. (2009): Microplate MPN-enumeration of monocyclic- and dicyclic-aromatic hydrocarbon degraders via substrate phase-partitioning. - Biodegradat 20:581-589.

[40] Johnston, A. E. (1986): Soil organic-matter, effects on soils and crops. - Soil Use Managem. 2:97-105.

[41] Juhos, K., Szabó, Sz., Ladányi, M. (2016): Explore the influence of soil quality on crop yield using statistically-derived pedological indicators. - Ecol. Indicat. 63:366-373.

[42] Juhos, K., Szabó, Sz., Ladányi, M. (2015): Influence of soil properties on crop yield: a multivariate statistical approach. Internat. - Agrophys. 29:433-440.

[43] Juhos, K. (2014): Methods of land evaluation and land use planning in international and Hungarian relations. - Földrajzi Közl. 138(2):122-133. (in Hungarian with English abstract)

[44] Hartmann, A., Schmid, M., VanTuinen, D., Berg, G. (2009): Plant-driven selection of microbes. - Plant Soil 321: 235-257.

[45] Helyes, L.; Pék, Z.; Daood, H. G.; Posta, K. (2015): Effect of mycorrhizae on main antioxidant content of processing tomato. - Acta Horticult. Technic. Comm. ISHS, 10-5110.

[46] Kaleeswari R. K. (2007): Role of phosphatase enzymes in phosphorus nutrition of crops. - Agr. Rev. 28:149-153.

[47] Khan, A. A., Ghulam, J., Akhtar, M. A., Naqui, S. M. S., Rasheed, M. (2009): Phosphorus solubilizing bacteria: Occurrence, mechanisms and their role in Crop Production. - J. Agric. Biol. Science. 1:48-58.

[48] Kloepper, J.W., Schroth, M. N. (1978): Plant growth promoting rhizobacteria on radishes. - Proc. Fourth Internat. Conf. Plant Path. Bact. (2) INRA, 879.

[49] Kloepper, J. W., Lifshitz, R., Zablotowiczm R. M. (1989): Free-living bacterial inocula for enhancing crop productivity. - Trends in Biotechnol. 7:39-43.

[50] Kocsis, T., Biró, B., Kotroczó, Zs. (2017): Time-lapse effect of ancient plant coal biochar on some soil agrochemical parameters and soil characteristics. - Env. Sci.Pollut. Res., doi: 10.1007/s11356-017-8707-0

[51] Kocsis, T., Biró, B. (2015): Effect of biochar on the soil-plant-microbe system: advantages and concerns - A Review. - Agrokém. Talajt. 64:257-272. (in Hungarian)

[52] Kocsis, T., Wass-Matics, H., Kotroczó, Zs., Biró, B. (2015): Biochar positively applicable of improving psychrophilic and mesophilic soilmicrobial counts. - In: Novel Waste-management strategies. (Ed. by Z. Futó). Szent Istvan University Press, p. 63-69. (in Hungarian)

[53] Kotroczó, Zs., Veres, Zs., Fekete, I., Krakomperger, Zs, Tóth, J. A., Lajtha, K., Tóthmérész, B. (2014a): Soil enzyme activity in response to long-term organic matter manipulation. - Soil Biol. Biochem. 70:237-243.

[54] Kotroczó, Zs., Veres, Zs., Biró, B, Tóth, J. A., Fekete, I. (2014b): Influence of temperature and organic matter content on soil respiration in a deciduous oak forest. Eurasian J. Soil Sci. 3:303-310.

[55] Kotroczó, Zs., Fekete, I., Tóth, J. A., Tóthmérész, B., Balázsy, S. (2008): Effect of leafand root-litter manipulation for carbon-dioxide efflux in forest soil. - Cer. Res. Comm. 36:663-666. 
[56] Libisch, B., Villányi, I., Füzy, A., Horváth, N., Biró, B. (2010): Identification and characterisation of bacterial strains capable to degrade aircraft de-icing fluids at four degrees. - J. Biotechnol. 1505:259.

[57] Malundo, T. M. M., Shewfelt, T. R. L., Scott, J. W. (1999): Flavor quality of fresh tomato as affected by sugar and acid level. - Postharvest Biol. Technol. 6:103-110.

[58] Mantelin, S., Touraine, B. (2004): Plant growth-promoting bacteria and nitrate availability: impacts on root development and nitrate uptake. - J. Experiment. Bot. 55:2734.

[59] Marshall, R. T. (1993): Standard methods for the examination of dairy products, 16th ed. - Americ. Publ. Health Associat. Washington, D.C.

[60] Mukherjee, A., Speh, D., Jones, A. T., Buesing, K. M., Diez-Gonzalez, F. (2006): Longitudinal microbiological survey of fresh produce grown by farmers in the upper Midwest. - J. Food Prot. 69:1928-3196.

[61] Oke, M., Ahn, T., Schofield, A., Paliyath, G. (2005): Effects of phosphorous fertilizer supplementation on processing quality and functional food ingredients in tomato. - J. Agric. Food Chem. 56:1531.

[62] Panwar, B.S., Kádár, I., Biró, B., Rajkai-Végh, K., Ragalyi, P., Rékási, M., Márton, L. (2011): Phytoremediation. Enhanced cadmium (Cd) accumulation by organic manuring, EDTA and microbial inoculants (Azotobacter sp., Pseudomonas sp.) in Indian mustard (Brassica juncea L.). - Acta Agronom. Hung. 59:101-107.

[63] Richardson, A. E., Hadobas, P. A., Hayes, J. E. (2001): Extra-cellular secretion of Aspergillus phytase from Arabidopsis roots enables plants to obtain phosphorus from phytate. - Plant J. 25:641-649.

[64] Rodriguez, H., Fraga, R. (1999): Phosphate solubilizing bacteria and their role in plantgrowth-promotion. - Biotechnol. Advances 17:319-339.

[65] Salles, C., Nicklaus, S., Septier, C. (2003): Determination and gustatory properties of taste-active compounds in tomato juice. - Food Chem. 81:395-402.

[66] Sariyer, T., Oztokat Kuzucu, C. (2015): Effects of Proline Applications on Yield and Quality Parameters in Kapija Pepper Grown under Different Irrigation Levels-2. Athens: ATINER'S Conference Paper Series, No: AGR 2015-1642.

[67] Schippers, B., Geels, F. R., Hoekstra, O., Lamers, J. G., Maenhout, C. A., Scholte, K. (1985): Yield depressions in narrow rotations caused by unknown microbial factors and their suppression by selected pseudomonads. - In: Ecology and management of soilborne plant pathogens. St. Paul (MN): The American Phytolog. Society. 462:127-130.

[68] Schmidt, B., Domonkos, M., Şumalan, R., Biró, B. (2010): Suppression of arbuscular mycorrhiza's development by high concentrations of phosphorous at Tagetes patula L. Res. J. Agricult. Sci. 44:156-162.

[69] Schweitzer, J. A., Bailey, J. K., Fischer, D. G., LeRoy, C. J., Lonsdorf, E. V., Whitham, T. G., Hart, S. C. (2008): Plant-soil-microorganism interactions: heritable relationship between plant genotype and associated soil microorganisms. - Ecology 89:773-781.

[70] Timmis, K. N. (2002): Pseudomonas putida: a cosmopolitan opportunist par excellence. Environ. Microbiol. 4:779-781.

[71] Tóth, J. A., Nagy, P. T., Krakomperger Zs, Veres, Zs., Kotroczó, Zs., Kincses, S., Fekete, I., Papp, M., Mészáros, I., Oláh, V. (2013): The Effects of Climate Change on Element Content and Soil pH (Síkfökút DIRT Project, Northern Hungary). - In: Kozak, J., Ostapowicz, K., Bytnerowicz, A., Wyzga, B. (eds.) The Carpathians: Integrating Nature and Society Towards Sustainability, Environmental Science and Engineering, SpringerVerlag Berlin Heidelberg, 77-88.

[72] Tóth, J. A., Lajtha, K., Kotroczó, Zs., Krakomperger, Zs., Caldwel, B., Bowden, R. D., Papp, M. (2007): The effect of climate change on soil organic matter decomposition. Acta Silv. Lign. Hung. 3:75-85.

[73] Varga, Cs., Fekete, I., Piskolczi, M., Dorka, D., Helmeczi, B. (2007): The effect of different mulching materials on quantitative changes of microbes in the soil of an 
integrated apple plantation. $-7^{\text {th }}$ Internat. Multidiscipl. Conf. N-Univ. Baia Mare. Sci. Bull. Serie C, XXI., 725-730.

[74] Veres, Zs., Kotroczó, Zs., Fekete, I., Tóth, J. A., Lajtha, K., Townsend, K., Tóthmérész, B. (2015): Soil extracellular enzyme activities are sensitive indicators of detrital inputs and carbon availability. - Appl. Soil Ecol. 92:18-23.

[75] Veres, Zs., Kotroczó, Zs., Magyaros, K., Tóth, J. A., Tóthmérész, B. (2013): Dehydrogenase activity in a litter manipulation experiment in temperate forest soil. Acta Silv. Lign. Hung.9:25-33.

[76] Vivas, A., Biró, B., Németh, T., Barea, J. M. (2006): Nickel-tolerant Brevibacillus brevis and arbuscular mycorrhizal fungus can reduce metal acquisition and nickel toxicity effects in plant growing in nickel supplemented soil. - Soil Biol. Biochem. 38:2694-2704

[77] Vladar, P., Rusznyak, A., Márialigeti, K., Borsodi, A. K. (2008): Diversity of sulfatereducing bacteria inhabiting the rhizosphere of Phragmites australis in Lake Velencei (Hungary) revealed by a combined cultivation-based and molecular approach. - Microb. Ecol. 56:64-75.

[78] Yang, J., Kloepper, J. W., Ryu, C. H. (2009): Rhizosphere bacteria help plants tolerate abiotic stress. - Trends Plant Sci. 14:1-4. 


\section{APPENDIX}

Appendix 1. Summarised data of estimated soil characteristics and tomato fruit quality parameters in the pot and field experiments with bioeffector inoculations (Budapest, Soroksár, 2014) (n=4)

\begin{tabular}{|c|c|c|c|c|c|c|c|c|}
\hline \multicolumn{9}{|c|}{ Data of pot experiment (average+/-standard error) } \\
\hline Treatments & $\begin{array}{l}\text { Harvest } \\
\text { (weeks) }\end{array}$ & MPN* & $\begin{array}{l}\text { Phosphorus } \\
\text { (mg/100g } \\
\text { soil) }\end{array}$ & $\begin{array}{c}\text { TSS } \\
\text { (g/sucrose/100g } \\
\text { solution) }\end{array}$ & $\begin{array}{c}\text { Glucose } \\
\text { (mg/100g fruit) }\end{array}$ & $\begin{array}{c}\text { Fructose } \\
\text { (mg/100g fruit) }\end{array}$ & $\begin{array}{l}\text { Citric acid } \\
(\mathrm{mg} / 100 \mathrm{~g} \\
\text { fruit })\end{array}$ & $\begin{array}{l}\text { Malic acid } \\
\text { (mg/100g } \\
\text { fruit })\end{array}$ \\
\hline Control & 10 & $5,42+/-0,61$ & $67,4+/-19,1$ & $6,62+/-0,16$ & $754,5+/-147,4$ & $516,3+/-102,6$ & $565,8+/-3,5$ & $295,4+/-1,3$ \\
\hline $\mathrm{BE}$ & 10 & $6,07+/-0,66$ & $101,9+/-7,3$ & $9,08+/-0,74$ & $1244,3+/-206,3$ & $645,9+/-71,3$ & $525,4+/-2,8$ & $222,2+/-9,9$ \\
\hline BR1-2 & 10 & $8,05+/-1,83$ & $90,4+/-12,7$ & $5,20+/-0,12$ & $638,6+/-16,6$ & $337,3+/-0,4$ & $261,0+/-3,2$ & $132,2+/-1,9$ \\
\hline \multicolumn{9}{|c|}{ Data of field experiment (average $+/$-standard error) } \\
\hline Treatments & $\begin{array}{l}\text { Harvest } \\
\text { (weeks) }\end{array}$ & $\mathrm{MPN}^{*}$ & $\begin{array}{l}\text { Phosphorus } \\
\text { (mg/100g soil) }\end{array}$ & $\begin{array}{c}\text { TSS } \\
\text { (g/sucrose/100g } \\
\text { solution) }\end{array}$ & $\begin{array}{c}\text { Glucose } \\
\text { (mg/100g fruit) }\end{array}$ & $\begin{array}{c}\begin{array}{c}\text { Fructose } \\
\text { (mg/100g fruit) }\end{array} \\
\end{array}$ & $\begin{array}{l}\text { Citric acid } \\
\text { (mg/100g } \\
\text { fruit) }\end{array}$ & $\begin{array}{c}\text { Malic acid } \\
(\mathrm{mg} / 100 \mathrm{~g} \\
\text { fruit })\end{array}$ \\
\hline \multirow[t]{2}{*}{ Control } & 10 & $6,80+/-0,72$ & $69,5+/-3,0$ & $3,36+/-0,05$ & $480,6+/-131,0$ & $258,3+/-45,3$ & $236,7+/-23,2$ & $110,9+/-21,3$ \\
\hline & 14 & & & $2,70+/-0,17$ & $631,6+/-58,4$ & $231,8+/-41,7$ & $281,2+/-0,1$ & $182,7+/-10,7$ \\
\hline \multirow[t]{2}{*}{$\mathrm{BE}$} & 10 & $6,30+/-1,08$ & $70,2+/-9,1$ & $5,16+/-0,15$ & $827,3+/-164,6$ & $408,6+/-56,1$ & $258,0+/-26,6$ & $112,8+/-4,9$ \\
\hline & 14 & & & $3,42+/-0,08$ & $579,7+/-164,6$ & $439,3+/-119,8$ & $380,8+/-17,8$ & $168,1+/-13,7$ \\
\hline \multirow[t]{2}{*}{ BR1-2 } & 10 & $6,02+/-1,35$ & $68,7+/-11,5$ & $4,70+/-0,01$ & $662,4+/-86,6$ & $355,2+/-56,1$ & $262,9+/-18,4$ & $74,7+/-2,4$ \\
\hline & 14 & & & $3,50+/-0,28$ & $523,5+/-8,5$ & $384,3+/-17,4$ & $307,6+/-7,6$ & $161,4+/-23,5$ \\
\hline \multirow[t]{2}{*}{$\mathrm{BE}+\mathrm{BR} 2$} & 10 & $6,59+/-0,99$ & $70,5+/-68,7$ & $5,22+/-0,08$ & $728,1+/-103,9$ & $355,2+/-38,9$ & $262,9+/-18,4$ & $85,8+/-13,2$ \\
\hline & 14 & & & $3,14+/-0,25$ & $364,5+/-2,8$ & $319,6+/-86,8$ & $326,2+/-6,0$ & $140,9+/-4,4$ \\
\hline
\end{tabular}

*Most probable number count of sporeforming bacteria $(\log 10)$ in soil.

Treatments: BE - Bioeffector treatment, inoculated by Bacillus amyloliquefaciens FZB42 strain (RhizoVital); BR1 - mixture of Bacillus subtilis, B. thüringiensis, B. megaterium strains (Biorex product); BR2 - mixture of Azotobacter chroococcum, Azospirillum lipoferum and Pseudomonas putida strains (Biorex product) 